\title{
THE DEVELOPMENT OF COGNITIVE INDEPENDENCE OF STUDENTS BASED ON INFORMATION TECHNOLOGY
}

\author{
Sharbanu Maygeldiyeva ${ }^{1, *}$, Bakytzhamal Bekzhanova ${ }^{1}$, Lazzat Zhamansarieva ${ }^{1}$, \\ Sholpan Stamkulova ${ }^{1}$, Gulnur Usenova ${ }^{1}$ \\ ${ }^{1}$ Korkyt Ata Kyzylorda State University, 120014, Kyzylorda, Republic of Kazakhstan
}

\begin{abstract}
In the article the authors consider the development of cognitive independence as the leading axiological motive for teaching students at the university. The authors believe that value attitude to the world allows the student to engage in cognitive activity with the whole variety of his or her inner strengths and capabilities. Based on this, the basis for the development of cognitive independence as a personality trait is to determine the personal meaning, needs and motives of the trainees, which is inextricably linked with the value orientations and axiological potential of the individual.

The article also states that cognitive independence successfully develops in the process of studying the discipline "Computer studies" at the university, where technological support for information and educational interaction is carried out by means of Web technologies. The study of the authors of the article shows that the implementation of this idea is based on the creation in the university of an information and communication environment as one of the leading trends in the development of university education and is implemented through the Platonus system, where the teacher's educational blog was created and forums were created both by the teacher and by themselves students. The authors note that the process of using new information technologies in the development of students' cognitive independence depends directly on teachers, and therefore, in the future they pay attention to the need to form their information technology culture.
\end{abstract}

\section{Introduction}

A high level of professional competence increases the competitiveness of the future specialist. Therefore, the main task of the training of future specialists in a modern university is the development of creative, cognitive abilities, which are formed with the effective organization of their cognitive independent activities.

On issues related to the development of the cognitive independence of the

\footnotetext{
* Corresponding author: sharban56@mail.ru
} 
individual, it should be emphasized that in science there is a significant amount of methodological, theoretical and applied research. At different times, both foreign and Russian scientists studied the problem of developing cognitive independence of individuals (A. Disterweg, E.Ya. Golant, B.P. Esipov, I.Ya. Lerner, M.N. Skatkin, N.A. Polovnikova, K .D. Ushinsky, T.I. Shamova, G.Ya. Shishmarenkova, G.I. Shchukina, Minakova T.V.), and Kazakhstani researchers (Zh.Karaev, T. Sabyrov, A. Abylkasymova, M. Zhanpeisova ) Russian and Kazakhstani scientists consider the problem of the development of cognitive independence of an individual in the educational process of higher education as socially important and humanitarian, suggesting various ways to solve it $[1 ; 2 ; 3 ; 4]$.

Based on the analysis of revealing what cognitive independence is, according to scientists of both from Russia and Kazakhstan, it can be stated that cognitive independence is a personality trait, based on which the intellectual abilities and competencies associated with the willingness and desire for independence in acquiring knowledge are highlighted and solve various educational problems. Based on their points of view, we believe that in the conditions of informatization of education, the student's cognitive independence is an integrative dynamic personal quality characterized by an optimal level of knowledge, a pronounced value attitude to cognition, a developed set of cognitive skills, competencies related to the ability and willingness of future specialists to initiative and professionally responsible activities in the field of computer science and computer knowledge [5, p. 56].

However, the analysis of scientific and pedagogical research and work experience have shown that the problem we are considering needs further research and experimental development from the point of view of applying information technologies.

\section{Result and discussion}

For our study in this direction, it is important to determine the cognitive independence of students as an indicator of the development of the axiological potential of a person (according to the concept of A. V. Kiryakova) [6]. Therefore, the further course of our research has allowed us, based on the application of empirical methods, such as observation, questioning (conversation, interviews, questionnaires), studying the products of the subjects 'activities (written, creative and control works), to first determine the meaningful characteristics (generalized indicators) of the development of students' cognitive independence University based on allocated components. (see table 1).

Table 1.Substantive characteristics of the components of the development of cognitive independence of students.

\begin{tabular}{|l|l|l|}
\hline Cognitive component & Value & Activity - based \\
\hline Knowledge (latitude, & - needs & Skills: \\
depth, volume): & - motives & - search \\
- about the world & - goals & - information \\
- about information & - interests & analytical \\
- professional & - aspirations & - creative \\
- sociocultural & - value - based & - reflective. \\
\hline
\end{tabular}

In accordance with the selected components, we have developed criteria: intellectual, axiological and praxeological (see table 2). 
Table 2. Criteria for the development of cognitive independence of students.

\begin{tabular}{|l|l|l|}
\hline \multicolumn{1}{|c|}{ Intellectual } & \multicolumn{1}{|c|}{ Axiological } & \multicolumn{1}{c|}{ Praxiological } \\
\hline $\begin{array}{l}\text { It characterizes cognitive } \\
\text { interest, motivation for } \\
\text { independent information } \\
\text { retrieval. }\end{array}$ & $\begin{array}{l}\text { It includes the notion that } \\
\text { knowledge is value, that motives } \\
\text { and value orientations contribute } \\
\text { to the development of cognitive } \\
\text { independence. }\end{array}$ & $\begin{array}{l}\text { Defines the possession } \\
\text { of skills for independent } \\
\text { information search, } \\
\text { includes self-assessment } \\
\text { and self-analysis of one's } \\
\text { own educational and } \\
\text { cognitive activity. }\end{array}$ \\
\hline
\end{tabular}

Table 3 Possibilities of information technologies in the development of cognitive independence of students

Taking into account the subject of our study, we came to the conclusion that the most accurate assessment of the levels of development of students' cognitive independence in computer science is advisable using the following indicators:

- knowledge of the theoretical foundations of independent activity; theoretical knowledge on the information picture of the world, on the use of information technology in the professional training of a future teacher of computer science acquired as part of independent work;

- the value attitude of students to educational and cognitive activities;

- the level of development of algorithmic, analytical and search skills associated with the degree of ownership of algorithms for storing, transmitting and processing information [7, p. 472-473].

Based on the selected indicators, we distinguish three levels of development of students' cognitive independence: high, optimal and sufficient. Further, taking into account the theoretical methods of analysis, synthesis, comparison, ranking, generalization, and systematization of the available material, we determined the possibilities of information technology in the development of cognitive independence of students in higher education of the Republic of Kazakhstan, which were clarified on the basis of the forms and methods of development of cognitive independence of pedagogical students in accordance with the objectives of teaching a computer science course at a university (see table 3 ).

Table 3. Possibilities of information technology in the development of cognitive independence of students.

\begin{tabular}{|l|l|l|}
\hline \multicolumn{1}{|c|}{ Learning Objectives } & \multicolumn{1}{|c|}{$\begin{array}{c}\text { Generalized indicators of cognitive } \\
\text { independence }\end{array}$} & $\begin{array}{l}\text { Educational and } \\
\text { technological } \\
\text { development } \\
\text { methods }\end{array}$ \\
\hline $\begin{array}{l}\text { The formation of a } \\
\text { worldview based on a } \\
\text { system-information } \\
\text { approach }\end{array}$ & $\begin{array}{l}\text { 1. Understanding the laws of information } \\
\text { processes. } \\
\text { 2. Knowledge of the types of information } \\
\text { and how to process it. } \\
\text { 3. Understanding the principles of } \\
\text { systematic information. of information } \\
\text { 4.Algorithmization of } \\
\text { retrieval. }\end{array}$ & $\begin{array}{l}\text { lectures; } \\
\text { electronic } \\
\text { portfolio; } \\
\text { compilation on } \\
\text { web-documents; } \\
\text { compiling an }\end{array}$ \\
\hline
\end{tabular}




\begin{tabular}{|c|c|c|}
\hline & $\begin{array}{l}\text { 5. Knowledge of the possibilities and } \\
\text { limitations of thinking automation. } \\
\text { 6. Ability to work in interactive mode } \\
\text { multimedia lectures; electronic portfolio; } \\
\text { compilation of web-documents; compiling } \\
\text { an annotated list of sources }\end{array}$ & $\begin{array}{l}\text { annotated list of } \\
\text { sources }\end{array}$ \\
\hline $\begin{array}{l}\text { The formation of the } \\
\text { operational style of } \\
\text { thinking }\end{array}$ & $\begin{array}{l}\text { 1. The ability to find the information } \\
\text { necessary to solve the problem. } \\
\text { 2. The ability to formulate a statement of } \\
\text { the problem for the goals and features of } \\
\text { the software. } \\
\text { 3. Understanding the principle of building } \\
\text { information systems. } \\
\text { 4. The ability to develop information } \\
\text { models to describe objects and systems. } \\
\text { 5. The ability to plan the structure of } \\
\text { actions necessary to achieve a given goal } \\
\text { using a fixed set of tools in information } \\
\text { retrieval). electronic portfolio; } \\
\text { compilation of wiki documents; compiling } \\
\text { an annotated list of sources; dialogue work }\end{array}$ & $\begin{array}{l}\text { electronic } \\
\text { portfolio; } \\
\text { compilation of } \\
\text { wiki documents; } \\
\text { compiling an } \\
\text { annotated list of } \\
\text { sources; dialogue } \\
\text { work }\end{array}$ \\
\hline $\begin{array}{l}\text { The formation of } \\
\text { personality traits and } \\
\text { qualities necessary for } \\
\text { the effective and safe } \\
\text { use of information } \\
\text { technology }\end{array}$ & $\begin{array}{l}\text { 1. Emotionally positive focus on activity as } \\
\text { the main way to solve educational } \\
\text { problems. } \\
\text { 2. An objective attitude to digital data, } \\
\text { based on information technology, personal } \\
\text { responsibility for decisions made on the } \\
\text { basis of computer data. } \\
\text { 3. Taking personal responsibility for } \\
\text { maintaining information security. } \\
\text { 4. The desire for self-affirmation through } \\
\text { creative activity using information } \\
\text { technology. } \\
\text { 5. Need and ability to work in a team when } \\
\text { solving complex problems by the } \\
\text { corporate method. }\end{array}$ & $\begin{array}{l}\text { multimedia } \\
\text { lectures; } \\
\text { electronic } \\
\text { portfolio; } \\
\text { compiling an } \\
\text { annotated list of } \\
\text { sources; dialogue } \\
\text { work }\end{array}$ \\
\hline $\begin{array}{lr}\text { The formation of the } \\
\text { ability } & \text { to } \\
\text { independently } & \text { and } \\
\text { effectively } & \text { solve } \\
\text { problems } & \text { using } \\
\text { information } & \\
\text { technology } & \end{array}$ & $\begin{array}{l}\text { 1. Digital literacy. } \\
\text { 2. Information independence. } \\
\text { 3. Cognitive activity. } \\
\text { 4. Information competence. }\end{array}$ & $\begin{array}{l}\text { electronic } \\
\text { portfolio; } \\
\text { compilation of } \\
\text { wiki documents; } \\
\text { compiling an } \\
\text { annotated list of } \\
\text { sources; dialogue } \\
\text { work }\end{array}$ \\
\hline
\end{tabular}

Based on the foregoing material we developed the model for the development of students' cognitive independence by means of information technology, which fully implements the corresponding capabilities of the national higher education system of Kazakhstan [8]. 
The characteristic of the model of development of students' cognitive independence by means of information technology is represented by informative, technological and effective units integrated with pedagogical conditions ensuring its effectiveness. The content block includes the components of the development of cognitive independence identified by us during the study. The technological unit is characterized by the directions of the teacher in organizing the development of cognitive activity of students through information technology. The resultant block includes the criteria (intellectual, axiological, praxiological) and the corresponding indicators for evaluating the expected result of the implementation of this model. This model is integrated with the pedagogical conditions of its effectiveness, such as the introduction of information technology in the content of the theoretical training of future teachers, the inclusion of search back in the independent activities of students, immersion of students in the information environment in the learning process.

The experimental work on the development of students' cognitive independence through information technology was carried out in three stages from 2015 to 2018 on the basis of Korkyt Ata KSU. 240 students of 1-4 years of pedagogical specialties and 25 teachers participated in it.

A stating experiment was conducted on the basis of a questionnaire method among students and teachers. So, one of the most important, in our opinion, questions was the question of what teachers understand by "student independence". $25.3 \%$ of the teachers surveyed believe that independence is a quality of the student's personality that helps him to fulfill what is the object of his or her cognitive activity; $28.6 \%$ of teachers believe that this is a form of manifestation of the activity of memory, creativity, thinking and imagination when a student performs a task given to him; $7.1 \%$ consider independence as a purposeful, internally motivated structured personality trait; $10.7 \%$ are of the opinion that this is also the independence of actions, work, the most cognitive activity as a readiness for innovations and innovations, for creativity; the remaining $17.8 \%$ are correlated with independent work and are considered as a way of educational activity, where the student is given tasks and guidance to them, work is carried out without participation, but under the guidance of a teacher, and its implementation requires a student mental stress. We concluded that all teachers adequately understand the essence of the concept of "independence", they do not have a common clear definition of this pedagogical category.

Since the basic category of our research is cognitive independence as the most important quality of a student's personality, it was important for us to find out the opinion of teachers about what, in their opinion, relates to the main signs of cognitive independence in the educational activities of students. The results of the survey let us draw the following conclusions:

- students often do independent work (51.9\%);

- $30.8 \%$ of students do independent work willingly; $51.9 \%$ make special efforts to do independent work;

- $25.9 \%$ of students need for knowledge; $57.7 \%$ of students show an average level of cognitive need; in $16.4 \%$ of students the need for knowledge is not expressed enough;

- according to teachers, such factors as student activity (46.4\%) will contribute to the development of students' cognitive independence; high student motivation $(85.7 \%)$; providing students with a wide selection of types of independent work $(92.8 \%)$; the use of information technology in the educational process (53.6\%);

According to teachers, the university provides opportunities for students to demonstrate their independence in educational activities. Among these opportunities, teachers named modern technical equipment of classrooms, the availability of computer classes in buildings, the Internet, the Platonus program, as well as the organization of scientific and practical conferences, competitions, thematic weeks, the creation of individual 
educational routes for students that contribute to the development of students' cognitive independence and much more.

Further research was based on the differentiation of the experimental and control groups. A study of the cognitive component involved questioning. A qualitative analysis of the data showed that there were no significant differences in the actual volume of concepts among students of the experimental and control groups (see table. 4.5).

Table 4. The level of formation of the cognitive component of students in the experimental group

\begin{tabular}{|c|c|c|c|}
\hline Criteria indicators & absence & partial presence & $\begin{array}{l}\text { maximum } \\
\text { presence }\end{array}$ \\
\hline & $\begin{array}{l}\% \text { from total } \\
\text { number }\end{array}$ & $\begin{array}{l}\% \text { from total } \\
\text { number }\end{array}$ & $\begin{array}{l}\% \text { from total } \\
\text { number }\end{array}$ \\
\hline Algorithmic skills & 8,0 & 47,5 & 44,5 \\
\hline Analytic skills & 1,5 & 69,6 & 28,9 \\
\hline Search Skills & 12,5 & 38,5 & 48,0 \\
\hline
\end{tabular}

Table 5.The level of the cognitive component of students in the control group

\begin{tabular}{|l|c|c|c|}
\hline \multirow{2}{*}{ Criteria indicators } & absence & partial presence & \multicolumn{2}{c|}{$\begin{array}{c}\text { maximum } \\
\text { presence }\end{array}$} \\
\cline { 2 - 5 } & $\begin{array}{l}\% \text { from total } \\
\text { number }\end{array}$ & $\begin{array}{l}\% \text { from total } \\
\text { number }\end{array}$ & $\begin{array}{c}\% \text { from total } \\
\text { number }\end{array}$ \\
\hline Algorithmic skills & 7,5 & 52,0 & 40,5 \\
\hline Analytic skills & 2,0 & 68,0 & 30,0 \\
\hline Search Skills & 2,0 & 42,4 & 55,6 \\
\hline
\end{tabular}

The study of the value component was carried out on the basis of tasks that students had to complete independently (see table 6).

Table 6.The levels of formation of the value component of students of the experimental and control groups at the beginning of the pedagogical experiment

\begin{tabular}{|c|c|c|}
\hline $\begin{array}{c}\text { Quantitative and qualitative } \\
\text { indicators }\end{array}$ & Experimental group & Control group \\
\hline $\begin{array}{c}\text { The level of formation of } \\
\text { motivation in the achievements in } \\
\text { the educational activity of } \\
\text { independence }\end{array}$ & $\%$ from total number & $\%$ from total number \\
\hline Fully owns these skills & 3,0 & 4,5 \\
\hline Owns partially & 76,5 & 66,7 \\
\hline Does not own these skills & 20,5 & 32,8 \\
\hline
\end{tabular}

The study of the activity component was carried out on the basis of tasks that students had to perform independently. As a result of the assignments, we recorded how much the students possess the skills to apply general knowledge, knowledge about the methods of cognition and computer knowledge, as well as be persistent, persistent in performing 
educational activities, the ability to exert efforts when doing independent work, the desire to bring the job to the final stage ( See table 7).

Table7.The level of formation of the activity component of students of the experimental and control groups at the beginning of the experiment.

\begin{tabular}{|c|c|c|}
\hline $\begin{array}{l}\text { Quantitative and qualitative } \\
\text { indicators }\end{array}$ & Experimental group & Control group \\
\cline { 2 - 3 } $\begin{array}{l}\text { The level of formation of skills } \\
\text { to apply computer knowledge } \\
\text { when completing tasks and to } \\
\text { conduct an independent search }\end{array}$ & $\%$ from total number & $\%$ from total number \\
\hline High level & & \\
\hline Average level & 5,5 & 6,7 \\
\hline Low level & 56,5 & 59,2 \\
\hline
\end{tabular}

Having assessed the state of each component during the ascertaining experiment on analysis, we were able to determine the level of development of students' cognitive independence. In this case, we relied on the methodology of the formal level of interpretation of results (N.I. Shevandrin), which involves "assigning a conditional number to certain properties and relationships" [9, p.138].

The level of formation of each component of the cognitive independence of students according to the findings of the ascertaining experiment was determined on a three-point scale: "1" point - low level, "2" point - average level, "3" points - a high level. The initial level was determined by deriving the average score for the three components (cognitive, value, activity) and relevant criteria. If the average score is in the range from 1 to 1.5 , we can talk about the low level of development of cognitive independence of students; from 1.6 to 2.4 about the average level; from 2.5 to 3 - about a high level. After processing according to this methodology for all students participating in the experiment, the following results were obtained (see table. 8).

Table 8.Calculation of the initial level of development of cognitive independence of students of the experimental and control groups.

\begin{tabular}{|c|c|c|c|c|}
\hline $\begin{array}{c}\text { Quantitative } \\
\text { and qualitative } \\
\text { indicators }\end{array}$ & $\begin{array}{c}\text { Level in } \\
\text { points }\end{array}$ & Overall score & $\begin{array}{c}\text { Average } \\
\text { score }\end{array}$ & $\begin{array}{c}\text { Initial } \\
\text { readiness }\end{array}$ \\
$\begin{array}{c}\text { Component } \\
\text { of readiness }\end{array}$ & 2 & & & \\
\hline Cognitive & 2 & & 1,66 & Average level \\
\hline Value & 1 & 5 & & \\
\hline Activity - based & 1,66 &
\end{tabular}

Subsequently, according to the research plan, a formative (training) experiment was organized and carried out, which consisted of 2 stages: at the first stage of the study, a methodology for the development of cognitive independence through information technologies was developed and offered to students, which consists in describing the 
information technologies used in the classroom to development of cognitive independence; at the second stage, the experiment was accompanied by the organization and conduct of additional classes on the topic: "Information technology in a modern school."

During the study, a system of independent work was developed using the capabilities of Web-technologies. The purpose of the developed system of independent work is the development of cognitive independence of students, its content is the assimilation of the curriculum in computer science. To search for information used: web browsers, databases, information retrieval and information and reference systems, automated library systems, electronic journals. To organize a dialogue on the network, email communication and the object-oriented dynamic learning environment Platonus were used. In computer studies classes, students of the pedagogical faculty used Web-quest technology, technology of forums for organizing virtual seminars (standard forum, simple discussion, each opens one topic, question-answer forum), e-mail (E-mail), creating a consortium, group and individual work $[10 ; 11 ; 12]$. The main purpose of the use of these technologies is aimed at students independently searching for information (knowledge) necessary for training. The survey results showed that $89 \%$ of students are completely satisfied with the work using this technology; it causes genuine interest and, according to the students themselves, increases their level of activity in finding the necessary information. The results of intermediate assessments and sessions in the study period also showed that students, in addition to basic knowledge, acquired the necessary professional competencies in the field of searching and using the necessary information and became more active users of the Internet system, distance learning. The main opportunities of distance learning in the study were carried out through the Platonus environment, which implements the network of "teacher-student". The Platonus system used in Kazakhstani universities supported file exchange of any format, both between a teacher and a student, and between students themselves; allowed to promptly inform all course participants or individual groups about current events, using the mailing service; accompanied the function of evaluating messages - both by the teacher and students; allowed to organize a training discussion of the problem in real time in chat.

As an additional program, we have developed a selection course for students of pedagogical specialties "Information Technologies in the Learning Process". The course is designed to assimilate 1 credit in the amount of 45 hours. The course program for students is aimed at systematization and expansion of knowledge in the field of new information technologies, the formation of an information culture and students' understanding of the possibilities of using information technology in the education of the modern information society.

At the final stage of the training experiment to identify the independence of future teachers in the application of information technology, we used the questionnaire "Methodology for determining the strength of cognitive needs" (V. S. Yurkevich) [13, p. 247250]. When analyzing the questionnaire aimed at revealing the cognitive independence of the teacher, the following results were obtained, which showed that $14 \%$ of students in the experimental group were characterized by active development on this issue, the development of independence strongly depends on the conditions - 54\%; weak development - 32\%, then after the experimental work indicators have changed significantly, active development of independence through information technology prevails among $56 \%$ of students, underdevelopment $-41 \%$, weak - $3 \%$ of students (see pic. 9). We associate the presence of positive dynamics primarily with the students' understanding of the importance of information technology in the development of cognitive independence. 


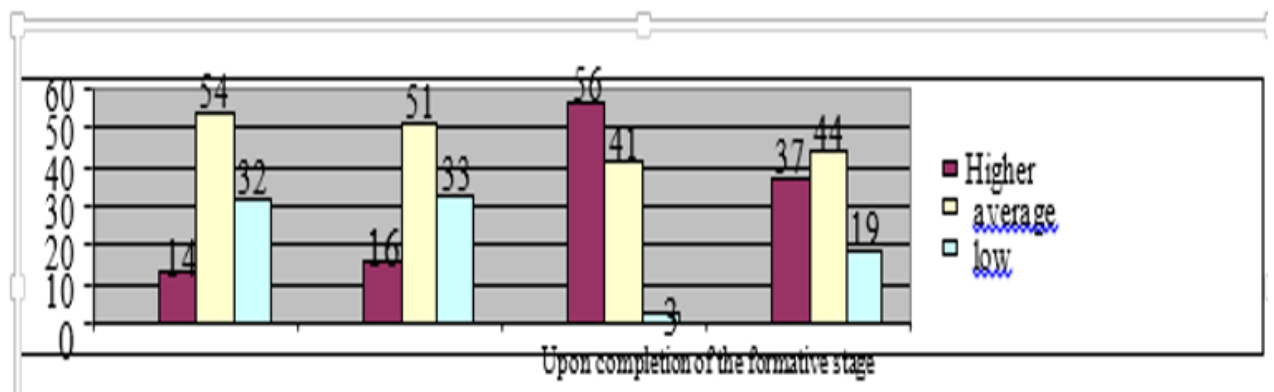

Fic.1. - Comparative dynamics of level indicators of the development of cognitive independence of students through information technology (in $\%$ of the number of respondents).

As a generalized conclusion on the results of the pilot work, we note: the comparative data obtained indicate that the goal is achieved, the tasks are solved, the hypothesis put forward has been confirmed by educational effectiveness.

\section{Conclusion}

Turning to cognitive independence as a pedagogical phenomenon, we note its importance in the future professional activities of a specialist experiencing personal needs for self-training, self-development and self-actualization.

Cognitive independence will be successfully developed in the process of studying the discipline "Information Studies" at the university, in which the development and transformation of needs, motives and goals into professional value orientations of initiative cognitive activities takes place. As the practical part of the study showed, the process of using new information technologies in the development of cognitive independence of students depends directly on teachers who carry out the modeling process and on the choice of specific technologies, therefore, when predicting possible ways of developing cognitive independence, it is necessary to take into account the level of awareness, interest, and ability to understand innovative process, intellectual and material resources as teachers and university students.

The results of the study allowed us to conclude that the pedagogical conditions implemented in the study are effective and necessary, according to which: the development of cognitive independence proceeds more successfully within the framework of a specially created information educational environment; directed activation of the subjective position of university students in the educational process of the university; an additional program is being introduced into the educational process for the course "Information Technologies in a Modern School" with the aim of preparing the future teacher to organize the independent work of schoolchildren using information technology.

In the future, stating that the modern teacher uses a variety of sources of information in his professional activity, and that our analysis of the state of students who are future teachers using modern means of information and information technology, we need to pay special attention to the following points: the information culture of the participants in the educational process; teacher computer literacy; technological competence of the teacher; the availability of information and communication technology in the classroom; motivation for its implementation in the educational process.

The study does not claim to be exhaustive and can serve as a promising direction for the development of research on the formation and development of information technology 
culture of the subjects of the educational process.

\section{References}

1. 1.Abylkasymova A.E. Formation of cognitive independence of students of preparatory departments in the process of studying a course of mathematics: Abstract ... dis. ped.sciences. Almaty, (1991)

2. Kurmanov M. Formation of cognitive activity of students in the preparation of future physics teachers at the university. Diss .... Doctor of Pedagogy. Karaganda, 2000

3. Minakova T.V. The development of cognitive independence of university students in the process of learning a foreign language [Electronic resource]: monograph / T.V. Minakova - Orenburg: GOU OGU, (2008)

4. Gvozdeva V.A. Basic and applied information technologies / Textbook. (2015)

5. Stamkulova Sh.A. The development of cognitive independence of students in the pedagogical realities of modern education / Sh.A. Stamkulova // Bulletin of the Orenburg State University№. 2. (2018).

6. Kiryakova A.V. Theory of personality orientation in the world of values / A.V. Kiryakova. Orenburg: Publishing House of the OGPI, (1996)

7. Stamkulova Sh.A., Kargapoltseva N.A. Indicators development of cognitive independence of students. University as a subject of research // Proceedings of the International scientific-practical conference "Innovative processes in modern science [Electronic resource] / Vydavatel" Osvícení ", Scientific and Publishing Center" World of Science ". - The electron. text. Prague, Czech Republic. p. 471-478 (2019)

8. Baimukhamediev S.K. New information technologies: a training manual. Almaty, (2003)

9. Shevandrin N. I. Social psychology in education. M .: Vlados, (1995)

10. Charles Crook. Web 2.0 technologies for learning: The current landscape opportunities, challenges and tensions / Crook Charles. 2008 : URL: http://www.becta.org.uk. (Date of access: February 22, 2018)

11. Soukup C. Building a theory of Multymedia CMC: An Analysis, critique and Integration of computer-mediated communications theory and research / C. Soukup // New Media and Society. London: Thousand Oaks, CA and New Delhy, (2001)

12. Viktorova T.S., Barmashov K.S., Mushkatova M.S. Organization of students' independent work using information technology - Modern educational technologies and methods for their implementation in the training system: Proceedings of the scientific and methodological conference. Vyazma: VF GOU MGIU, (2011)

13. Zubkova M. A.1, Fominykh N., Baranova E., Abbasova L., Maigeldiyeva Sh.M. Approaches to the future engineers foreign communicative culture formation // Humanities \& Social Sciences Reviews (eISSN: 2395-6518, Vol 7, No 4, p. 781-786; https://doi.org/10.18510/hssr.2019.74101) (2019)

14. Yurkevich V.S. To the question of cognitive needs of schoolchildren // Some relevant psychological and pedagogical problems of upbringing and upbringing education. M.,(p. 247-250) (1976)

15. Saparkysy Ж. The formation and development of cognitive activity of students in the learning process. // International Journal of Environmental and Science Education ((Turkey), ISSN: 1306-3065, Vol. 11. Iss. 18., P. 12235-12244.) (2016)

16. Saparkyzy Zh. Mental activity of students on the background of physical education classes. // collection int. conf. Europen scientific conference. Penza, 2018 
17. Maygeldieva Sh.M., Saparkyzy Zh., The concept of health-saving education is an integral part of the humane type of education // Bulletin of the Kazakh National Pedagogical University named after Abay, № 1, 2019

18. Saparkyzy Zh., Maygeldieva Sh., Ayaganova A., Koldasova L.S. Densaulyқ saқtauda Ynemdeytin oқуtu tekhnologlaryn қоldanudyн keyyr aspectileri. // Bulletin of the Kazakh National Pedagogical University named after Abay №1, 2019 